\title{
Productivity of Arable Crop Farmers: Panacea to Youth Unemployment
}

\author{
Ashagidigbi Waheed $\mathbf{M}^{* 1}$, Yusuf Taibat $\mathbf{M}^{2}$ and Agboola Uthman $\mathbf{O}^{1}$ \\ ${ }^{1}$ Department of Agricultural and Resource Economics, Akure, Nigeria \\ ${ }^{2}$ Department of Agricultural Economics and Extension, Malete, Nigeria
}

*Corresponding author: Ashagidigbi Waheed M, Department of Agricultural and Resource Economics, Akure, Nigeria

\section{ARTICLE INFO}

Citation: Ashagidigbi Waheed M, Yusuf Taibat M, Agboola Uthman O. Productivity of Arable Crop Farmers: Panacea to Youth Unemployment. Biomed J Sci \& Tech Res 22(4)-2019. BJSTR. MS.ID.003792.

Keywords: Youth Farmers; Arable Crops; Productivity; Frontier Production Function

\begin{abstract}
Nigerian agricultural sector is known to be dominated by aged and inactive famers who are less productive and less receptive to new ideas. This has led to reduced food productivity, which is a threat food security in the country. This necessitates the need to involve youths in agriculture. This study examined and compared the productivity of the youths and aged arable crop farmers in Nigeria, to empirically establish how productive youths are in comparison to the aged in order to increase food production and reduce unemployment. The data used were obtained from General household survey panel (GHSP) and Living Standards Measurement Study (LSMS) 2015/2016 data collected by National Bureau of Statistics (NBS) [1]. A total of 2,134 old and young arable crop farmers were selected. The data were analysed using descriptive statistics, t-test and stochastic frontier analysis. The study revealed that majority of the farmers are old. Youth farmers cultivates 1.249 ha compared to 1.628 ha cultivated by old farmers. The output of youth farmers $(10194.74 \mathrm{~kg} / \mathrm{ha})$ is significantly higher than that of the aged arable crop farmers (7897.816kg/ha). All the inputs used positively influence productivity, likewise, access to credit has a direct effect on the technical efficiency of the arable crop farmers. It is recommended that youths should be encouraged to venture into arable crop farming in order to increase productivity and reduce youth unemployment. Income smoothening policy option such as credit provision should also be executed in order to enhance the efficiency of the youths in crop production.
\end{abstract}

\section{Introduction}

Agriculture was the backbone of the Nigeria economy for many decades before the discovery of petroleum in commercial quantity. CBN [2] reported that out of the 3.402 billion naira contributed by the non-oil sector to the GDP, agriculture contributed as much as $1,623.45$ billion naira, which is $47.71 \%$ of total non-oil production. However, agricultural productivity contribution to GDP in Nigeria has declined from about $90 \%$ before independence to about $41 \%$ between 2001 and 2005 [3]. This scenario has induced tremendous increase in the country's import bills from about 8 billion naira in 1996 to over 183 billion naira in 2005 [3]. Thus, food production could not keep pace with the population growth, resulting in rising food imports and declining levels of national food self-sufficiency. According to FMARD [4], Ayanwale and Amusan [5] in 2010 alone, Nigeria spent $\$ 635$ billion on importation of wheat, $\$ 356$ billion on rice to bridge the demand and supply gap.
Nigeria has a land area of about 91 million hectares and 82 million of this total land mass is said to be cultivable. Unfortunately, a little over 40 per cent of this arable land is used for farming [6]. Agricultural production in Nigeria is growing at a rate of $2.5 \%$ per annum which is insufficient in satisfying the needs of the population growing at alarming rate of $3.5 \%$ per annum. Amaza et al. [7] estimated that the annual food supply in Nigeria would have to increase at an average annual rate of 5.9 percent to meet the food demand and reduce food importation significantly. Aside the issue of rising food import bills, Nigeria agriculture is faced with serious problems that prevent reasonable development and cause decline in agricultural production. An important one is labour, which is a key input in agricultural production because it is central to other farming activities. Agricultural labour forces comprise mainly old people and few numbers of youth. However, youths have 
been known to possess dynamic energies, creative activities and adventurous spirit. So, the development of youth determines the development of the country. Okogun [8] define the youthful period as the time when a man's skills and attributes are developed to highest potentials. It is a period when man's intellect is at its highest peak. According to Okogun [8], Fajans et al. [9], youths could be described as any person between the age of 16 and 30 years, which make up 80 percent of the total population and as well constitute about 76 percent of agricultural labour force. International Labour Organization, [10] put the age range between 18 and 35 years.

In Nigerian agricultural sector, average age of farmers was 53.4 years $[1,11,12]$ also posited that farming population in Nigeria are ageing, with an average age of 47 years and life expectancy at 47-50 years. Overwhelming increase in population figure in Nigeria to over 170 million has caused demand for agricultural produce to out strip supply [13]. This is however dangerous to agricultural development in that the aged farmers who are fragile, less productive and less receptive to new ideas dominate the agricultural sector in Nigeria. Thus, this group need to be reinforced by the more productive youths. Past studies have shown that older people are less receptive to new ideas and are less inclined to accept agricultural innovations than younger people $[14,15]$. These are serious disincentives for an agriculturally based nation that will participate in emerging world economy. In order to enhance food production and eliminate food insufficiency in Nigeria, there is the need to involve youths in agriculture who can easily adapt to new farm techniques and technologies. This will prevent mass unemployment and lack of sustainable livelihood activities among the youths as posited by Arimi and Ewebiyi [16]. This study was set out to examine the involvement of youths in arable crop farming and compare their productivity with that of the aged. It also examined the determinants of arable crop production in Nigeria. This is necessary in order to showcase agriculture as a career youths could engage in. Aside this, Involvement of youths in agriculture would increase production, reduce food import bills, prevent rural-urban migration and provide employment for the teeming unemployed youths in Nigeria.

\section{Methodology}

The study is Nigeria. Secondary data obtained from the General household survey panel (GHSP) and Living Standards Measurement Study (LSMS) 2015/2016 collected by the National Bureau of Statistics (NBS) were used for this study. A total of 2,134 respondents in both rural and urban areas participated in providing necessary information needed for the study. Information on the socioeconomic characteristics of the arable crop farmers, output of major arable crops (maize, rice, beans, sorghum and cassava) and key farm inputs (fertilizers, seeds, chemicals and labour) were extracted from the data. Descriptive statistics, T-test and Frontier production model were the analytical techniques adopted. Descriptive statistics (frequency, percentage, mean) was used to analyse the socioeconomic characteristics of the famers, the inputs used, and the output of major arable crops considered. T-test was used to determine whether significant difference exists between the output of the aged and young farmers. Frontier Production function was used to examine the determinants of the arable crop farmers in the study area. The stochastic frontier was used to analyse Objective 3. The stochastic production frontier consists error term $E \mathrm{i}$, which can be separated into two components: a stochastic random error component (random shocks) and a technical inefficiency component so that one can identify focal points for action to bring efficiency to higher levels.

The stochastic production frontier function specified for the research is given below:

$\mathrm{Yi}=\mathrm{F}(\mathrm{Xi}: \beta)+\varepsilon \mathrm{i}$

(where $i=1,2,3 \ldots, n$ ),

$\varepsilon \mathrm{i}=\mathrm{Vi}+\mathrm{Ui}$

Yi = Farm Output (Grain Equivalent/ha) from ith farm.

This implies the summation of major arable crops in Nigeria, such as rice, maize, sorghum, cassava and beans in $\mathrm{Kg} / \mathrm{ha}$ (Grain equivalent)

$\mathrm{X}_{1} \mathrm{i}=$ Farm Size (Hectare)

$\mathrm{X}_{2} \mathrm{i}=$ Labour (Man days)

$\mathrm{X}_{4} \mathrm{i}=$ Planting materials $(\mathrm{kg})$

$\mathrm{X}_{5} \mathrm{i}=$ Fertilizer $(\mathrm{kg})$

$\mathrm{X}_{6} \mathrm{i}=$ Herbicides (Litre)

$\mathrm{X}_{7} \mathrm{i}=$ machinery $(\mathrm{N})$

$\beta=$ Vector of $\mathrm{k}$ number of parameters to be estimated

$\mathrm{Vi}=\mathrm{It}$ is assumed to account for measurement's error and other factors not under the control of the farmers. It will be assumed to be independent and identically distributed random errors having normal $\mathrm{N}(0, \boldsymbol{\sigma} 2 \mathrm{v})$ distribution and independent of Ui.

$\mathrm{Ui}=\mathrm{Ui}$ are non-negative random variables, called technical inefficiency effects which are assumed to be half normally distributed $\mathrm{N}(0, \boldsymbol{\sigma} 2 \mathrm{u})[17]$.

\section{$\beta=$ Vector of unknown parameters to be estimated}

$\varepsilon \mathrm{i}=$ Error term: the symmetrical disturbance which captures the random error effects on output. It accounts for error and other factors beyond the control of the farmer and it is also assumed to be independently and identically distributed as $\mathrm{N}\left(\mathrm{O}, \mathrm{S}_{-} \mathrm{v}^{\wedge} 2\right)$,

Other vital parameters estimated under this analysis include sigma square $\left(\sigma^{2}\right)$, gamma $(\gamma)$ and log- likelihood ratio. $\sigma^{2}$ indicates the goodness of fit of the model used, and gamma gives the proportion of the deviation of the output from the production 
frontier caused by technical inefficiency. For example, if $\gamma=0$, it indicates that Ui is absent in the model. If $\gamma=1$, it means all deviations from the frontier are due to technical inefficiency. The log-likelihood ratio is used to test for the significant presence of technical inefficiency effects in farmers' production. The loglikelihood ratio statistic has asymptotic distribution equal to chisquare distribution. The variance parameters of the model are parameterized as given below:

$$
\sigma 2 \mathrm{~s}=\sigma 2 \mathrm{v}+\sigma 2 \mathrm{u}
$$

The variance parameters are expressed below;

$$
\gamma=\sigma 2 \mathrm{u} / \sigma 2 \mathrm{~s} .
$$

$\gamma=$ parameter lies between zero and one. $(0 \leq \gamma \leq 1)$

Where,

$\sigma 2 \mathrm{~s}=$ Variance parameters of sample statistic

$\sigma 2 \mathrm{v}=$ Variance of the error term due to noise

$\sigma 2 \mathrm{u}=$ Variance of the error term resulting from technical inefficiency

In order to estimate technical efficiency for the third objective; [17], technical efficiency of the farmer is expressed below.

$\mathrm{TEi}=\mathrm{Yi} / \mathrm{Yi}^{*}$, where,

$$
\begin{aligned}
\mathrm{Yi} & =\mathrm{F}(\mathrm{Xi}: \beta) \varepsilon(\mathrm{Vi}-\mathrm{Ui})=\varepsilon(-\mathrm{Ui}) \\
\mathrm{Yi}^{*} & =\mathrm{F}(\mathrm{Xi}: \beta) \varepsilon(\mathrm{Vi}) \ldots \ldots \ldots \ldots \ldots \ldots \ldots \ldots \ldots \ldots \ldots \ldots
\end{aligned}
$$

Where, $\mathrm{TE}=$ Technical efficiency of the $\mathrm{i}^{\text {th }}$ farmer

$\mathrm{Yi}=$ Observed output of the $\mathrm{i}^{\text {th }}$ farmer (Grain Equivalent) $\mathrm{kg} / \mathrm{ha}$

$\mathrm{Yi}^{*}=$ Potential output (Grain Equivalent) kg/ha
$0 \geq \mathrm{TE} \leq 1$ (technical efficiency ranges between 0 and 1 )

Conditioned on the level of input used by the farmers Battese and Coelli [18]. The empirical model Technical efficiency can be defined as the ability of a decision-making unit (e.g. a farm) to produce maximum output given a set of inputs and technology. For technical inefficiency, the truncated-normal distribution is a generalization of the half-normal distribution. It is obtained by the truncation at zero of the normal distribution with mean $\mu$ and variance, $\sigma 2 \mu$. Some farmers' characteristics will be incorporated into the frontier functions as it is believed that they have direct influence on efficiency.

The inefficiency function is specified as:

$$
\mu_{\mathrm{i}=} \sigma_{0+} \sigma_{1} \mathrm{Z}_{1 \mathrm{i}}+\sigma_{2} \mathrm{Z}_{2 \mathrm{i}+} \sigma_{3} \mathrm{Z}_{3 \mathrm{i}+} \sigma_{4} \mathrm{Z}_{4 \mathrm{i}+} \sigma_{5} \mathrm{Z}_{5 \mathrm{i}+} E i
$$

$\mathrm{Ui}=$ Production inefficiency of the $\mathrm{i}^{\text {th }}$ farmer

$Z_{1}$ represent farms age group of farmers in years; $(0=$ youth, $1=$ aged). This is achieved using the ILO, 2005 definition of youth.

$Z_{2}$ represents the region of production ( $1=$ rural, $0=$ urban)

$\mathrm{Z}_{3}$ represents the sex $((1=$ female, $0=$ male $)$

$\mathrm{Z}_{4}$ represents the household size

$\mathrm{Z}_{5}$ represents the extension reach ( $1=\mathrm{yes}, 0=$ no)

$\mathrm{Z}_{6}$ represents the access to credit $(1=$ yes, $0=$ no $)$

The $\sigma_{\mathrm{n}}$ are unknown parameters to be estimated. $E i$ is an error term, independent and identically distributed and obtained by truncation of the normal distribution with zero mean and constant variance $\sigma^{2}$.

\section{Results and Discussion}

Table 1: Socioeconomic Characteristics of the Respondents in the study Area.

\begin{tabular}{|c|c|c|c|c|}
\hline Youth & Aged & & & Percentage \\
\hline Variables & Frequency & Percentage & Frequency & $90.46 \%$ \\
\hline Age & 210 & 9.48 & 1924 & 89.45 \\
\hline Mean & 31.7 & 55.4 & 1 & 10.55 \\
\hline Sex Male & 209 & 99.5 & 203 & 29.8 \\
\hline Female & 1 & 0.48 & 573 & 70.2 \\
\hline Credit- (Had Access) & 36 & 17.2 & 1351 & 9.88 \\
\hline Access (No Access) & 174 & 82.8 & 1734 & 90.12 \\
\hline Sector (Urban) & 15 & 7.14 & 190 & 13.2 \\
\hline (Rural) & 195 & 92.86 & 13.8 & 86.8 \\
\hline Extension-(Yes) & 29 & 86.2 & & \\
\hline Reach-(No) & 181 & & & \\
\hline Land Size/Hectare & & 55.7 & & \\
\hline$<1.00$ & 84 & 40 & 2.4 & \\
\hline
\end{tabular}




\begin{tabular}{|c|c|c|c|c|}
\hline $10.01-15.00$ & 2 & 0.95 & 14 & 0.7 \\
\hline Above 15.00 & 2 & 0.95 & 5 & 0.26 \\
\hline Mean & \multicolumn{2}{|c|}{1.628} & \multicolumn{2}{|c|}{1.249} \\
\hline \multicolumn{5}{|l|}{ Household Size } \\
\hline $0-5$ & 86 & 40.9 & 447 & 23.23 \\
\hline $6-10$ & 109 & 51.9 & 1049 & 54.52 \\
\hline $11-15$ & 14 & 6.7 & 385 & 20 \\
\hline $16-20$ & - & - & 33 & 1.7 \\
\hline Above 20 & 1 & 0.47 & 10 & 0.52 \\
\hline Mean & \multicolumn{2}{|c|}{6} & \multicolumn{2}{|c|}{8} \\
\hline
\end{tabular}

Source: (GHSP) and (LSMS) 2015/2016.

Table 1 revealed that over $90 \%$ of the farmers in Nigeria are old, conforming to the findings of Adeogun $[1,11,12]$ that agricultural sector in Nigeria is dominated by aged farmers. This would probably have effect on their productivity and efficiency. Youth and aged Male farmers constituted almost 10 and 9 out of every 10 farmers respectively. This is an indication that arable farming in Nigeria is male dominated, in line with the findings of Ashagidigbi et al. [19]. This could probably be since females are more involved in the processing of farm produce in comparison to farming. As expected over $90 \%$ of both youths and aged farmers are from the rural areas, aligning with the submission of Ashagidigbi et al. [20], that majority of farmers are domiciled in the rural areas. Majority of the arable crop farmers had no access to credit. This may impede their production and expansion capacity as credit is a propelling tool for farmers to increase production. The mean hectare cultivated by the two groups indicated that both are operating at small scale level cultivating below 2 hectares. However, the mean hectares cultivated by the youths depict their probable higher productivity than the aged. Majority of both groups also did not have access to extension services. The average household size of 6 and 8 for the youths and aged farmers respectively showed that the size of the households of arable crop farmers is relatively high. This is in line with the finding of Ashagidigbi et al. [19], that quoted 8 members as the mean value.

Table 2: Average Input Used by the Arable Crop Farmers.
Table 2 profiled the quantity of inputs used by both aged and youth farmers in Nigeria. Youth farmers used more of labour, seed, machineries and fertilizers more than the aged farmers. The aged however utilised more of land (1.62 hectares) than average youth farmer (1.429 hectares). Aged farmers also used more of herbicides and pesticides in their respective farms in comparison to farmers that are young. The land productivity profile of arable crop farmers in Nigeria as shown in Table 3 revealed that the productivity of youths is higher for all the crops considered except for beans. This is an indication that youths arable crop farmers are more productive than their aged counterpart. As revealed in Table 4, the difference between the output/hectare of aged and arable crop farmers was significant at $10 \%$ level, indicating that the output of the youth farmers significantly outweighs that of the aged. Table 5 shows the estimated coefficient of the production frontier and their corresponding levels of statistical significance. All the coefficients of production function have the expected signs. The results showed that pesticide, labour, herbicide, fertilizer, seed, Machinery and land size are significant at $1 \%$ level, except cost of seed which its coefficient is positive but insignificant. Therefore, the positive coefficients of these inputs imply that they enhance the productivity of arable crop farmers in the study area. This is in consonance with the findings of [21-23], who found out that agricultural inputs such as farm size, chemicals and fertilizers positively influence the productivity of farmers.

\begin{tabular}{|c|c|c|c|c|}
\hline & \multicolumn{2}{|c|}{ Aged } & \multicolumn{2}{c|}{ Youth } \\
\hline Variable & Mean & Std. Dev. & 1.249584 & Std. Dev \\
\hline Land_size* & 1.627847 & 3.594638 & 827.0463 & 810.569 \\
\hline Labor_total & 624.181 & 703.0153 & 2776.56 & 6183.706 \\
\hline Value_her dde* & 3411.429 & 7443.416 & 1352.339 & 3829.629 \\
\hline Value_pes de* & 2028.581 & 6654.193 & 3094.669 & 19854.8 \\
\hline Cost_seed & 1410.638 & 4757.133 & 1406.861 & 8865.305 \\
\hline Value_mach t & 905.2381 & 4123.41 & 90.55916 & 332.6662 \\
\hline Fert_inorg g & 77.33336 & 142.1468 & & \\
\hline
\end{tabular}

Source: (GHSP) and (LSMS) 2015/2016. 
Table 3: Productivity of arable crop farmers in Nigeria.

\begin{tabular}{|c|c|c|c|c|}
\hline \multicolumn{2}{|c|}{ AGED } & \multicolumn{2}{c|}{ YOUTHS } \\
\hline Crops & Mean (kg/ha) & Standard Deviation & Mean (kg/ha) & Standard Deviation \\
\hline Maize & 3559.887 & 10317.2 & 4862.986 & 12714.65 \\
\hline Rice & 406.8125 & 1422.893 & 644.1035 & 2926.478 \\
\hline Sorghum & 2415.914 & 8378.166 & 2805.502 & 9664.506 \\
\hline Cassava & 525.0675 & 3318.144 & 1102.535 & 4185.695 \\
\hline Beans & 990.1347 & 2716.84 & 779.6145 & 2624.801 \\
\hline
\end{tabular}

Source: (GHSP) and (LSMS) 2015/2016.

Table 4: Test between the Mean Output of the Aged and Arable Crop Farmers.

\begin{tabular}{|c|c|c|c|c|}
\hline Group & Mean & Standard Error & Standard Deviation & T-test \\
\hline Youth & 10194.74 & 471.6123 & 20686.53 & -1.7219 \\
\hline Aged & 7897.816 & 1247.797 & 18082.3 & \\
\hline Combined & 9968.708 & 442.7419 & 20452.57 & \\
\hline Difference & -2296.925 & 1333.948 & & \\
\hline
\end{tabular}

Source: (GHSP) and (LSMS) 2015/2016.

Table 5: Determinants of the Productivity of Arable Crop Farmers.

\begin{tabular}{|c|c|c|c|c|}
\hline Variables & Coefficient & Standard error & Z-ratio & P>|z| \\
\hline Constant $\beta 0$ & 8.840377 & 0.2419725 & 36.53 & 0.000 \\
\hline Pesticide $\left(\mathrm{X}_{1}\right)$ & 0.0539683 & 0.0089327 & 9.04 & 0.000 \\
\hline Labour $\left(\mathrm{X}_{2}\right)$ & 0.3413392 & 0.0346104 & 8.45 & 0.000 \\
\hline Herbicide $\left.\mathrm{X}_{3}\right)$ & 0.0670355 & 0.0079341 & 4.20 & 0.000 \\
\hline Fertilizer $\left(\mathrm{X}_{4}\right)$ & 0.0571192 & 0.0136058 & 0.03 & 0.978 \\
\hline Cost of seed $\left.\mathrm{X}_{5}\right)$ & 0.0002241 & 0.0082956 & 3.68 & 0.000 \\
\hline Machinery $\left(\mathrm{X}_{6}\right)$ & 0.0539498 & 0.0146656 & 7.82 & 0.000 \\
\hline Land size $\left(\mathrm{X}_{7}\right)$ & 0.1090132 & 0.013943 & & 0.13 \\
\hline Inefficiency model $_{\text {Constant }}$ & & & 2.58 & 0.000 \\
\hline Credit access $\mathrm{Z}_{1}$ & 1.504506 & 0.2453993 & 0.40 & 0.010 \\
\hline Age group $\mathrm{Z}_{2}$ & 0.2291089 & 0.0888757 & 4.70 & 0.691 \\
\hline Sex $\mathrm{Z}_{3}$ & 0.0637512 & 0.1601637 & -5.79 & 0.000 \\
\hline Household size $\mathrm{Z}_{4}$ & 0.6060951 & 0.1289642 & 0.42 & 0.000 \\
\hline sector $\mathrm{Z}_{5}$ & -0.0838343 & 0.0144778 & -3.80 & 0.678 \\
\hline Ext-reach $\mathrm{Z}_{6}$ & 0.0567158 & 0.1365977 & & 0.000 \\
\hline Sigma- squared $\delta^{2}$ & -0.5178866 & 0.1362623 & & \\
\hline Gamma $(\gamma)$ & 4.905015 & 0.2492181 & & \\
\hline
\end{tabular}

Log likelihood function $=-3851.1308$.

Source: (GHSP) and (LSMS) 2015/2016.

The significant value of sigma squared $\mathrm{d}^{2}$ shows the presence of inefficiency effects in arable crop production, while the significant gamma $(\gamma)$ of 0.4647 indicates that about $46.47 \%$ variation in output of the arable crop production would be attributed to technical inefficiency effects. The mean inefficiency value of $34.7 \%$ indicates that arable crop farmers in the study area are $65.3 \%$ efficient as shown in Table 6. The effect of arable crop farmers' socio-economic characteristics (inefficiency variables) on technical efficiency was also examined. The signs and magnitude of the coefficients of the variables have important policy implications on technical efficiency of farmers. The result revealed that extension reach and household size have negative and significant effect on the technical efficiency of the farmers, implying that extension reach and household size tend to reduce the technical efficiency of the arable crop farmers in the study area, conforming with submission of Ashagidigbi [23], who also found out that access to extension services had negative effect on technical efficiency of farmers. Access to credit and sex of the household head however increase 
the farmers' technical efficiency by $22.9 \%$ and $60.6 \%$ respectively. This is an indication that farming households that are headed by males and those that have access to credit have improved technical efficiency than those headed by females with no access to credit. This is expected as male farmers tend to be more actively involved in arable crop production than their female counterpart who are more involved in processing activities. Farmers' access to credit facilities also provide an impetus to purchase the desired inputs necessary for their production. These findings are in conformity with that of Yusuf and Malomo [22,24].

Table 6: Distribution of technical inefficiency estimates of arable crop farmers in the study area.

\begin{tabular}{|c|c|c|}
\hline Efficiency level & Frequency & Percentage \\
\hline $0.00-0.20$ & 595 & 27.9 \\
\hline $0.21-0.40$ & 610 & 28.5 \\
\hline $0.41-0.60$ & 726 & 34.1 \\
\hline$>0.60$ & 203 & 9.5 \\
\hline
\end{tabular}

Mean inefficiency $=0.3470284$.

Source: (GHSP) and (LSMS) 2015/2016.

\section{Conclusion}

In conclusion, the study established that majority of farmers in Nigeria are old. Also, though the population of youths in arable crop production is minute, their productivity is however significantly higher than that of the aged. The frontier production analysis revealed that all the inputs used (seeds, fertilizers, herbicides, pesticides and seeds) have positive and significant effect on arable crops farmers' productivity in Nigeria. Also, access to credit facilities significantly influence technical efficiency of arable crop farmers positively. It is however recommended that youths should be encouraged to undertake arable crop farming as source of livelihood in order to increase food production and reduce youth unemployment problems in the country. Also, credit facilities should be provided to the farmers to enhance their efficiency in food production in ensuring food security (one of the Sustainable development goals) in the country.

\section{References}

1. NBS (2008) National Bureau of Statistics (NBS) publications.

2. CBN (2002) Central Bank of Nigeria Annual Report and Financial Statements.

3. Central Bank of Nigeria CBN (2005) Annual report and statement of Accounts, Central Bank of Nigeria 224.

4. FMARD (2011) Nigeria's Agricultural Transformation Agenda. Mid Term Review.

5. Ayanwale AB, Amusan CA (2012) Gender Analysis of Rice Production Efficiency in Osun State: Implication for the Agricultural Transformation
Agenda. Paper presented at the $13^{\text {th }}$ National Conference of the Nigerian Association of Agricultural Economists, Obafemi Owolowo University.

6. International Labour Organisation (ILO) (2005) Youth: Pathways to decent work International Labour. Promoting youth employment Tackling the challenge employment Conference.

7. Amaza PS, Umeh JC, Helsen, Adejobi AO (2006) Determinants and Measurement of Food Insecurity in Nigeria: Some Empirical Policy Guide. Contributed Poster prepared for presentation at the International Association of Agricultural Economists Conference, Gold Coast, Australia.

8. Okogun SA (2004) Youths' participation in farming activities in Edo state. An unpublished B. Sc project in the Department of Agricultural Extension and Rural Development University of Ibadan, Ibadan Nigeria pp. 3-5.

9. Fajans D, Zaletta K, Lamb D, Kleinman S (2205) Lack of Resources for Rural Youth - How an Extension Help?

10. Bakare AS (2011) A Theoretical Analysis of Capital Formation and Growth in Nigeria, Far East Journal of Psychology and Business, Far East Research Centre 3(2): 11-24.

11. Adeogun SO (2008) Adoption of cocoa rehabilitation techniques among cocoa farmer in Nigeria. Ph.D. Thesis, Department of Agricultural Extension and Rural Development, University of Ibadan, Ibadan, Nigeria.

12. Oboh V, Sani RM (2009) The role of radio on the campaign against the spread of HIV/AIDS among farmers in Markudi, Nigeria. Journal of Social Sciences 19(3): 179-184.

13. Kakwa VV, Ikubah A (2010) Youths Unemployment in Nigeria. Causes and Related Issues. Canadian Social Science 6(4): 231- 237.

14. Laogun EA (1991) The activities of agric. input services units (AISIS) in Egbedore local Government of Osun State. Ife J Agric 13: 114-120.

15. Balogun AL (2000) Adoption of alley farming among farmers in Osun State, Nigeria PhD Thesis. OAU Ile-ife.

16. Arimi K, Ewebiyi IO (2013) Barriers of Youths' Participation in Farming Activities in Developing Countries: The Case of Akinyele Local Government Areas of Oyo State, Nigeria. Academia Arena 5(10): 22-29.

17. Aigner DJ, Lovell CAK, Schimidt P (1977) Formulation and estimation of Stochastic frontier Function models. Journal of Econometrics 6: 21-37.

18. Battese, Coelli (1995) A Model for Technical Inefficiency Effects in a Stochastic Frontier Production Function for Panel Data. Empirical Economics 20(2): 325-332.

19. Ashagidigbi Waheed Mobolaji, Sulaiman Adesina Yusuf; Rasheed Adebola Olubodun (2017) Economic Burden of Conflicts on Farmers' Output in South-west Nigeria. Science Letters 5(3): 217-224.

20. Ashagidigbi Waheed M, Abiodun O Falusi, Samson O Awopeju (2011) The Effects of Rural Infrastructure Development on Crop Farmers' Productivity in Osun State. World Rural Observations 3(1): 48- 58.

21. Adesoji SA, Farinde (2006) Socio-Economic Factors Influencing Yield of Arable Crop in Osun State, Nigeria. Asian Journal of Plant Sciences 5(4): 630-634.

22. Yusuf SA, Malomo O (2007) Technical Efficiency of Poultry Egg Production in Ogun State. A Data Envelopment Analysis (DEA) Approach. Int J Poult Sci 6: 622-629.

23. Ashagidigbi WM, Sulaiman SA, Adesiyan A (2011) Technical and Allocative Efficiency of Poultry Egg Producers in Nigeria. Agricultural Journal 6 (4): 124-130.

24. Kuta DD (2004) GM Technology to benefit farmers in Nigeria agbionet. 


\section{ISSN: 2574-1241}

DOI: 10.26717/BJSTR.2019.22.003792

Ashagidigbi Waheed M. Biomed J Sci \& Tech Res

CC (P) This work is licensed under Creative (c) ${ }_{\mathbf{B Y}}$ Commons Attribution 4.0 License

Submission Link: https://biomedres.us/submit-manuscript.php

$\begin{array}{ll}\text { BIOMEDICAL } & \text { Assets of Publishing with us } \\ \text { RESEARCHES } & \text { Global archiving of articles } \\ & \text { - Immediate, unrestricted online access } \\ & \text { - Rigorous Peer Review Process } \\ \end{array}$

